ppi $201502 Z U 4645$

Esta publicación científica en formato digital es continuidad de la revista impresa ISSN-Versión Impresa 0798-1406 / ISSN-Versión on line 2542-3185Depósito legal pp $197402 Z$ U34
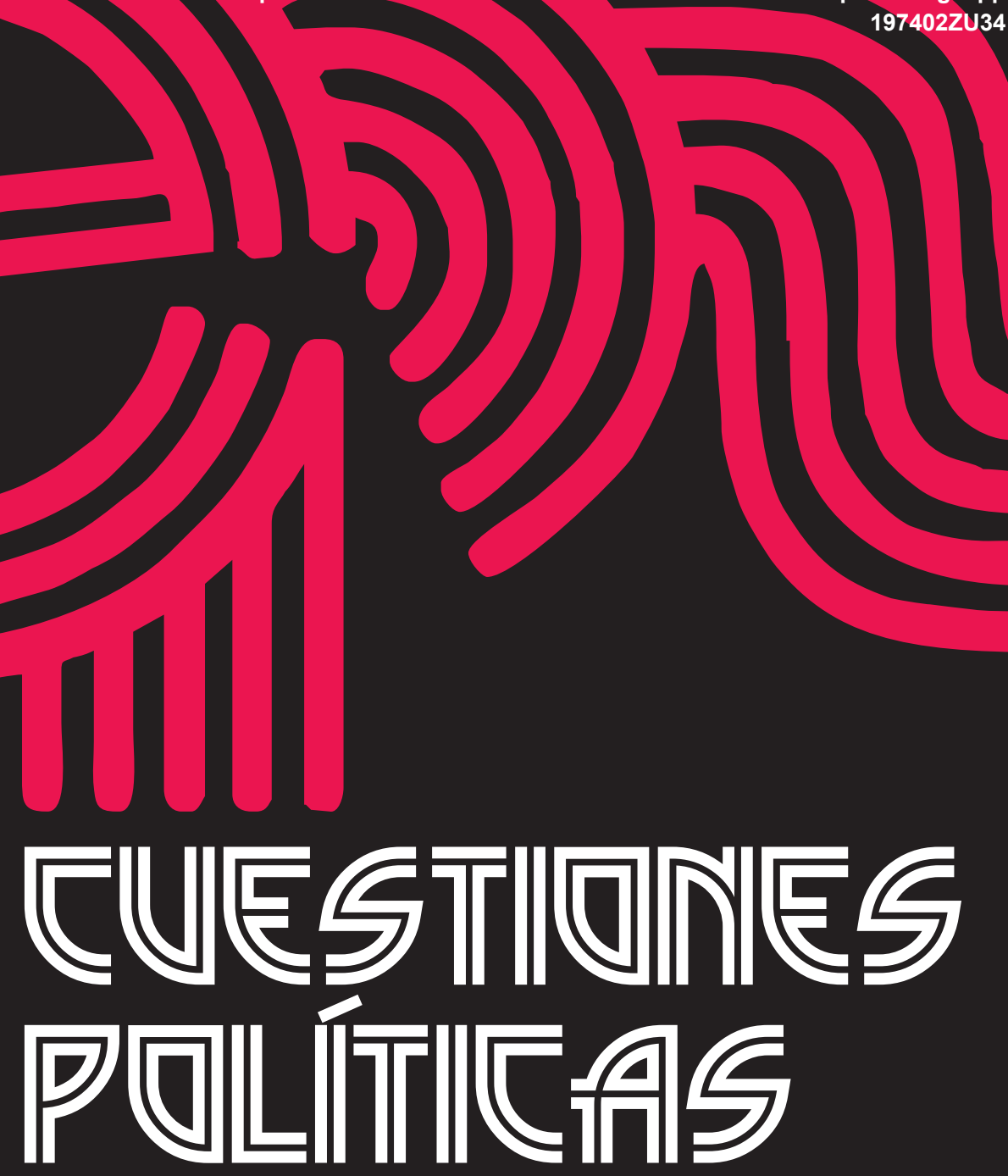

Instituto de Estudios Políticos y Derecho Público "Dr. Humberto J. La Roche" de la Facultad de Ciencias Jurídicas y Políticas de la Universidad del Zulia Maracaibo, Venezuela
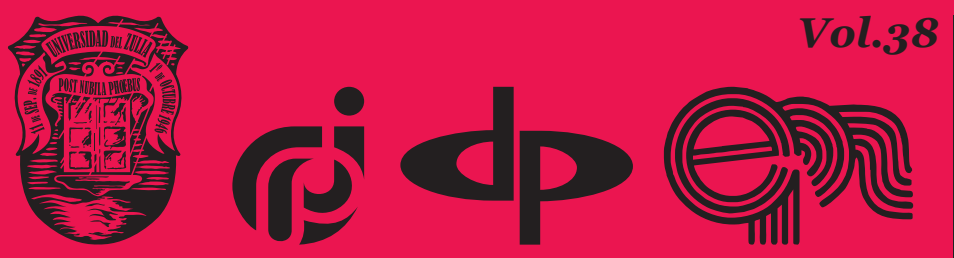

$N^{\circ}$ Especial 2da Parte 2020 


\title{
Dynamics of the implementation of the protective role in the conduct of crimes: the practice of the Convention for the Protection of Human Rights and Fundamental Freedoms
}

\author{
DOI: https://doi.org/10.46398/cuestpol.382e.33
}

\author{
Dariia Balobanova * \\ Anastasiia Otsyatsya *** \\ Mykhailo Dmytruk **** \\ Anastasiia Khylchenko *****
}

\section{Abstract}

Criminal law offers the possibility of interfering with human life. To avoid such unjustified interference, society and the state must guarantee that human and civil rights are protected and that the standards established in the Convention for the Protection of Human Rights and Fundamental Freedoms are observed. Therefore, it is important to analyze the dynamics of the implementation of the protective function in the conviction of crimes in the interpretation of the European Court of Human Rights ECHR. In the methodological, he made of dialectics and documentary observation. The work aims to analyze the practice of the European Court of Human Rights, which tracks the dynamics of the protection function in sentencing for crimes. As a result of the study, the dynamics of the protection function in sentencing for criminal offenses were clarified through the practice of the ECHR, the problematic issues of the implementation of the protection function were analyzed in the

* Ph. D., Associate Professor of Department of Criminal Law. National University «Odesa Law Academy»Odesa, Ukraine. ORCID ID: https://orcid.org/oooo-0001-7247-0560. Email: dbalobanova@ukr.net

** Ph. D., Associate Professor of Department of Criminal Law. National University «Odesa Law Academy»Odesa, Ukraine. ORCID ID: https://orcid.org/oooo-ooo1-6589-3143. Email: irynagorbachova15@ gmail.com

*** Ph. D., Associate Professor of Department of Criminal Law. National University «Odesa Law Academy»Odesa, Ukraine. ORCID ID: https://orcid.org/oooo-0oo3-2203-4861. Email: a.s.otsyatsya@gmail. com

**** Ph. D., Associate Professor of Department of Criminal Law. National University «Odesa Law Academy»- Odesa, Ukraine. ORCID ID: https://orcid.org/oooo-ooo2-7170-2144. Email: onuamd@ gmail.com

*****Ph. D., Associate Professor of Department of Criminal Law. National University «Odesa Law Academy»- Odesa, Ukraine. ORCID ID: https://orcid.org/oooo-0oo2-2997-3354. Email: akhylchenko25.onua@gmail.com 
example of Ukraine and foreign countries, and proposals were made, to use the practice of the ECHR as a "living tool" for the protection of human and civil rights and freedoms.

Keywords: human rights protection function; criminal sentences; crimes; jurisprudence of the European Court of Human Rights; legal practice.

\section{Dinámica de la implementación de la función protectora en la condena por delitos: la práctica del convenio para la protección de los derechos humanos y de las libertades fundamentales}

\section{Resumen}

El derecho penal ofrece la posibilidad de interferir en la vida humana. Para evitar tal injerencia injustificada, la sociedad y el estado deben garantizar que los derechos humanos y civiles estén protegidos y que se observen los estándares establecidos en la Convención para la Protección de los Derechos Humanos y las Libertades Fundamentales. Por tanto, es importante analizar la dinámica de la implementación de la función protectora en la condena por delitos en la interpretación de la Corte Europea de Derechos Humanos TEDH. En lo metodológico se hizo de la dialéctica y de la observación documental. El trabajo tiene como objetivo analizar la práctica de la Corte Europea de Derechos Humanos, que rastrea la dinámica de la función de protección en la condena por delitos. Como resultado del estudio, se aclaró la dinámica de la función de protección en la sentencia por infracciones penales a través de la práctica del TEDH, se analizaron las cuestiones problemáticas de la implementación de la función de protección en el ejemplo de Ucrania y países extranjeros, y se formularon propuestas, para usar la práctica del TEDH como una "herramienta viva" para la protección de los derechos y libertades humanos y civiles.

Palabras claves: función de protección de los derechos humanos; sentencias de orden penal; delitos; jurisprudencia del Tribunal Europeo de Derechos Humanos; práctica jurídica. 
Dariia Balobanova, Iryna Gorbachova, Anastasïa Otsyatsya, Mykhailo Dmytruk y Anastasiia Khylchenko

\section{Introduction}

The Constitution of Ukraine proclaims that a person, his life, health, honor and dignity, inviolability, and security are the highest social values. The Constitution stipulates that the state is responsible for its activities before the person and to guarantee the possibility of enjoying all human and civil rights and freedoms, the state must provide a mechanism for exercising the rights and freedoms guaranteed by the Convention for the Protection of Human Rights and Fundamental Freedoms (1950) (hereinafter - Convention).

One of the main tasks of the Criminal Law of Ukraine (2001) is to protect the basic and most important for humans, society, and the state public relations from criminal encroachments. This is an integral function of criminal law, which is enshrined in Part 1 of Art. 1 of the Criminal Code of Ukraine (hereinafter - the CC of Ukraine).

The protective function is provided by establishing the range of socially dangerous acts that are recognized os crimes, as well as criminal penalties and other measures of criminal-legal influence applied to the perpetrators. In the protection of public relations in this way, criminal law also regulates other public relations - those that arise between the state and a person who has committed a socially dangerous act to prosecute such a person.

As provided in the Constitution of Ukraine (1996), there are international mechanisms for the implementation of the security function in Ukraine. One of these is the Convention (1950) and the application of ECtHR judgments in sentencing for criminal offenses. Among the fundamental principles of international law are "the right to a fair trial", "no punishment without law", "the right to appeal in criminal cases", "compensation in case of unlawful conviction", "and the right not to be prosecuted or punished twice". Besides, the Convention stipulates that the criminalization of certain acts is a violation of the standards of the Convention, and prosecution to exercise a protective function is a disproportionate restriction of the rights provided by the Convention.

Given the provisions of the Convention and the case-law of the ECtHR, the importance of the protection function to ensure law and order and human and civil rights and freedoms, it is important to analyze how the case-law of the ECtHR affects the dynamics of the implementation of this function in sentencing for the commission of criminal offenses, the peculiarities of the enforcement of ECtHR decisions by Ukrainian courts and possible prospects in this topic.

Thus, the work aims to analyze the practice of the European Court of Human Rights, which traces the dynamics of the protection function in 
sentencing for criminal offenses. The object of the study is social relations, that arise during the implementation of the protection function in sentencing for criminal offenses.

Given the above, firstly, the methodology will be described; then the theoretical basis of the study will be provided; after that, the key research findings will be presented and discussed in the next section. As a result of the study, the conclusion will be drawn.

\section{Methodology}

In studying the dynamics of the protection function in sentencing for criminal offenses through the practice of the ECtHR used such methods of scientific knowledge as analysis method, comparison method, dialectical method, historical method, the system method, abstraction method, modeling method, induction method, and deduction method.

Thus, the method of analysis allowed us to comprehensively consider the social relations that arise, change, and cease during the implementation of the protective function in the sentencing of criminal offenses. This method facilitated the consideration of the subject of study through foreign experience in regulating the protection of state-guaranteed rights during sentencing, legislation, and case law of Ukraine, as well as the case-law of the European Court of Human Rights.

Moreover, the dialectical method allowed us to consider the development of decisions of the ECtHR on the implementation of the protective function in sentencing for criminal offenses, and to analyze the categories of "crime" and "punishment" in their relationship and development. The method of the comparison made it possible to compare the dynamics of the protection function in the sentencing of criminal offenses in Ukraine and abroad, as well as to investigate how the practice of the ECtHR in Ukraine and the world.

In addition, the historical method allowed to analyze the dynamics of the protection function in sentencing for criminal offenses through the practice of the ECtHR in different periods and under the influence of factors specific to a particular period (changes in legislation, revolution, change of government). A systematic method helps to comprehensively investigate the dynamics of the protection function in sentencing for criminal offenses through the practice of the ECtHR, namely through the study of criminal proceedings, human rights by law enforcement agencies, the use of ECtHR practice in judicial decisions and public control over human rights and freedoms when sentencing for a criminal offense as elements that develop over time and are elements of the system necessary for the implementation of the protective function. 
Furthermore, the method of modeling allowed simulating the further dynamics of the implementation of the security function in the sentencing of criminal offenses, taking into account the dynamics of public relations. The method of abstraction made it possible to deviate from the analysis of the dynamics of the protection function in sentencing for criminal offenses in modern conditions and to design the possible development and manifestations of the protection function in the future. Thus, it is noted that depending on the legal regulation and implementation of control mechanisms, changes in the practice of the judiciary, depends on the understanding and dynamics of the protection function.

The method of induction was used in the study of general theoretical provisions on crime and punishment and the protective function of criminal law.

A deduction was used to identify and verify the assertion that the implementation of the protection function in Ukraine depends on the specific conditions that the national legal system can provide.

\section{Analysis of Recent Research}

At present, the question of the implementation of constitutional rights and freedoms of man and citizen in the context of Covid-19 is just beginning to be studied by scientists and is extremely relevant.

Firstly, it should be mentioned the Tsiura, Kharchenko, and Sabodash (2020) noted that the ECtHR's legal position played a significant role in extending the interpretation of "property rights". Given the increasing use of judicial precedent (which is the ECtHR's decisions), the Ukrainian legal system cannot ignore the requirements and standards set by the decision of international courts.

Moreover, as Drobush, Olkina, Vodopian, But (2019) stated, one of the tasks of the pro-European integration of any of the states, which now expresses the desire for EU membership, is the task of further building and strengthening the state as a legal and social one.

Further, Vashakidze (2019), in her work, drew attention to the protection of the rights of juvenile offenders while serving their sentences in different countries, drawing attention to the protective function of criminal law. The researcher analyzed the experience of Japan, the USA, Great Britain, Australia, Sweden, France, and other countries to compare the state of protection of the rights of minors in different countries, as well as identified the application of the Convention in these countries. 
Moreover, Gotorova (2014) studied the protective function of criminal law, its features, the specifics of the manifestation, and implementation. Thus, in her work, the author considered the implementation of the criminal law of its protective function and formulated approaches to the rules of interaction of criminal law with the rules of other branches of law in the exercise of protective functions.

Drozdov (2017), Slutska (2019) carried out a comprehensive analysis of the case-law of the European Court of Human Rights as a European guideline to ensure the sustainability and unity of judicial practice by the Supreme Court. In addition. Kovalsky (2010) studied the historical conditionality of the protective function of law, its development, and the dynamics of implementation. In his work, I. Kolesnikov (2019) tried to get an answer as to whether Ukrainian judges are ready for amendments to the legislation, including the application of the case-law of the European Court of Human Rights.

Besides, Nafikova (2010) analyzed the protection of human and civil rights in foreign countries. In the article, Nafikova considered the regulations governing the protection of criminal justice and programs conducted in foreign countries to protect the rights of participants in criminal proceedings, including in countries such as the United States, Britain, and Germany.

Khilyuk (2015) analyzed the "crime and punishment" in the Convention for the Protection of Human Rights and Fundamental Freedoms, namely, drew attention to how the provisions of the Convention protect the rights of participants in criminal proceedings during the proof of guilt and sentencing.

Thus, from the analysis of the above literature, we can conclude that scholars insufficiently study the dynamics of the protection function in sentencing for criminal offenses through the practice of the ECtHR, and therefore there is a need for a comprehensive study of this topic.

\section{Results}

The purpose of Human Rights is twofold, on the one hand, to serve as a legal framework and epistemological for the development of a universal conception of the human dignity that provides men and women in their worlds of life, sufficient and necessary conditions for the development of their capacities that. On the other hand, they represent or should represent, for the democratic nations of the world today, a retaining wall against the possible arbitrary use of the power of the elites (formal and factual) to definitively overcome: the practices, actions or omissions, that condemn 
Dariia Balobanova, Iryna Gorbachova, Anastasïa Otsyatsya, Mykhailo Dmytruk y Anastasiia Khylchenko

432

Dynamics of the implementation of the protective role in the conduct of crimes: the practice of the Convention for the Protection of Human Rights and Fundamental Freedoms

large sectors of society to a life of poverty, exclusion, violence, calamity and all kinds of equity (Arbeláez-Campillo et al., 2018).

Before analyzing the dynamics of the implementation of the security function in sentencing for criminal offenses through the prism of the caselaw of the European Court of Human Rights, it is necessary to define the key concept - the security function.

In general, public relations has always needed protection. With the advent of law, it becomes one of the most important means of protecting public relations. Such influence is a protective function. The protective function makes it possible to distinguish the right from other systems of social regulation, as it is carried out by state bodies that make individual government decisions, the implementation of which is guaranteed by state coercion. Thus, the protective function contributes to the development in law as a regulator of social relations of valuable qualities for the individual and society, including stability, detailed and clear regulation, and clear procedures.

It is a direction of legal influence, which is due to social purpose and is aimed at protecting the most important, most important economic and political relations, overcoming phenomena that are foreign to this society.

Protecting these relations, it is important to timely prevent and punish actions that violate the conditions of normal development and are contrary to the interests of society, state, and citizens and thus displace them, and this is the main task of this function.

The protective function is realized through a special way of influencing the behavior of people, which is expressed in the impact on their consciousness by the threat of sanctions, prohibitions, and legal liability informs the public about what social values are protected by law and is an indicator of political and the cultural level of society, the humane principles contained in the law.

The method of protection very often depends on the development of society, its political essence, and therefore the analysis of the dynamics of the protection function, including the imposition of punishment for criminal offenses. International legal instruments come to the aid of national authorities. One of such tools is the case-law of the European Court of Human Rights on the research issue, which reflects how public relations are ensured at the present stage.

According to Art. 1 of the Constitution of Ukraine (1996), Ukraine is a sovereign and independent, democratic, social, legal state. Person, his/her life and health, honor and dignity, inviolability and security are recognized in Ukraine as the highest social value; human rights and freedoms and their guarantees determine the content and direction of the state, which is 
responsible to man for his activities; the establishment and protection of human rights and freedoms is the main duty of the state.

According to Art. 9 of the Constitution of Ukraine (1996), the Convention for the Protection of Human Rights and Fundamental Freedoms, ratified by Ukraine is part of national legislation.

According to the rules of Part 4 of Art. 9 of the Criminal Procedure Code of Ukraine (2012) (hereinafter - the CPC of Ukraine) if its provisions contradict the international agreement, the binding nature of which was approved by the Verkhovna Rada of Ukraine, the provisions of the relevant international agreement of Ukraine shall apply in criminal proceedings. Besides, the content of Part 5 of Art. 9 of the CPC of Ukraine, the criminal procedure legislation of Ukraine is applied, taking into account the practice of the ECtHR.

This obligation is also imposed on the court given Art. 17 of the Law of Ukraine "On Enforcement of Judgments and Application of the Case Law of the European Court of Human Rights" (2006), which stipulates that courts use the Convention and the case-law of the European Court of Human Rights as a source of law when considering cases.

Article 19 of the Convention (1950) provides that, to ensure compliance by the States Parties to the Convention, their obligations under the Convention and its Protocols, a European Court of Human Rights shall be established and shall function permanently. The Contracting Parties undertake to comply with the final decisions of the Court in any case to which they are parties.

Thus, in view of the above, it can be concluded that the courts (to ensure the unity of judicial practice, in particular, in terms of its compliance with international standards, administering justice, in addition to national law) should apply the rules of the Convention. As the Convention (1950) has several characteristics, its provisions are general in nature, and human rights are mostly stated in it in an abstract, evaluative form, the correct understanding of its rules is revealed in ECtHR decisions, which contain legal positions on the essence of the provisions of this international legal act, as well as the content and scope of the guaranteed rights (Law of Ukraine, 2006).

The application by courts of the provisions of the Convention and / or specific legal positions of the ECtHR is often abstract and does not always correspond to the circumstances of the criminal case and national law. There are also frequent cases of violation by the courts in criminal cases of the requirements of Articles 3, 5, 6 of the Convention, which leads to violations of citizens' rights and repeated appeals to the ECtHR.

Consider the dynamics of the protection function in sentencing in the practice of the ECtHR in more detail. 
Dariia Balobanova, Iryna Gorbachova, Anastasïa Otsyatsya, Mykhailo Dmytruk y Anastasiia Khylchenko

In an important judgment in the case of Selmoni v. France (1999), the ECtHR found that Art. 3 of the Convention embodies the fundamental values of democratic societies that are members of the Council of Europe and is considered one of the most important fundamental provisions of the Convention, derogation from which is not allowed and in case of a complaint under this article of the Convention, the ECtHR must carry out a particularly thorough analysis, taking into account all the material submitted by the parties.

Also in cases when a person raises an unfounded complaint that he was subjected to improper treatment by the subjects of power in violation of Art. 3 of the Convention (1950), it is necessary to conduct an effective formal investigation aimed at identifying and punishing those responsible.

Violation of Art. 3 of the Convention in Grigoryev v. Ukraine (2012) in its procedural aspect was found in connection with the ineffectiveness of the investigation into the applicant's complaints of ill-treatment by law enforcement officers and the repeated closure of the case due to shortcomings in the investigation and disregard all available medical documents in the case (Law and Business, 2012). Thus, before violating the procedural requirements of Art. 3 of the Convention resulted in an ineffective investigation of the applicant's complaints, which were substantiated. The case-law of the European Court of Human Rights on the application of Art. 3 of the Convention indicates the following mandatory conditions for compliance with the obligations of the Convention in this part:

1. the imperative obligation to investigate complaints of persons in criminal proceedings about ill-treatment;

2. the obligation to establish all the factual circumstances under which the person was subjected to ill-treatment, with a specific decision based on the results of the relevant complaints.

Ineffective investigation of complaints led to a violation of Art. 3 of the Convention in its substantive aspect.

Violation of the requirements of Art. 3 of the Convention in its procedurais aspect in the case of Klishin v. Ukraine (2012) was recognized by the ECtHR due to the ineffectiveness of the investigation into the applicant's complaints of ill-treatment given that it was characterized by numerous shortcomings recognized by the national authorities.

In the practice of the ECtHR on compliance with the provisions of paragraph 1 of Art. Article 5 of the Convention requires that deprivation of liberty be "lawful", in particular following the "procedure established by law". Therefore, the Convention (1950) refers to the provisions of national law and establishes the obligation to ensure compliance with substantive and procedural law, but it also requires that the purpose of Art. 
5 of the Convention (1950), in particular, the protection of persons against arbitrariness. According to the case-law of the ECtHR, national authorities, in particular, courts, must interpret and apply national law under Art. 5 of the Convention. Thus, violation of the requirements of paragraph 1 of Art. 5 of the Convention in the case of Mocallal v. Ukraine (2011) established that the applicant had been detained based on a court decision that had no proper legal basis.

The ECtHR drew attention to the importance of observance of court procedures and protection of the rights of the accused during sentencing in the case of Iglin v. Ukraine (2012). Thus, another criminal case was instituted against the applicant while he was serving his sentence. On an unspecified date, the case against the applicant and several other persons was referred to the Court of Appeal, which acted as a court of the first instance. The applicant was found guilty of the crimes charged and sentenced to life imprisonment, after which the applicant complained that the Supreme Court of Ukraine had unfairly denied his requests for additional time to examine the case file and ensure the presence of counsel at the hearing. The applicant relied on Article 6 of the Convention, which provides for the right to a fair and public hearing within a reasonable time by an independent and impartial tribunal established by law, which must establish the merits of any criminais charges against him. In the light of the applicant's and the Government's submissions, the Court notes that the Convention guarantees the accused "adequate time and facilities necessary to prepare his defense" to exercise his protective function, and therefore this guarantee means that the preparation of defense may essentially involve on his part of all "necessary measures". The accused must be able to organize his defense properly and without prejudice to the opportunity to present to the trial court all the necessary arguments of the defense and thus to influence the outcome of the proceedings. The means necessary for anyone accused of committing a criminal offense include the opportunity to review the results of investigations conducted throughout the proceedings. The court listed factors relevant to the establishment of the limits of the obligation of public authorities to ensure the rights of the accused. These include the gravity of the charges against the applicant and the severity of the punishment that may be imposed on the applicant. Therefore, this case confirms that the ECtHR pays considerable attention in determining how and under what conditions the punishment for a criminal offense was imposed, whether all procedural provisions of criminal procedural law were complied with and whether the state was able to protect both the perpetrator and other participants in the process through a security function.

For example, in Ruslan Yakovenko v. Ukraine (2015), the applicant complained that his detention and reference to the provisions of the Convention under which everyone had the right to liberty and security of person. Also, in the present case, the applicant argued that if he had decided 
Dariia Balobanova, Iryna Gorbachova, Anastasïa Otsyatsya, Mykhailo Dmytruk y Anastasiia Khylchenko

to appeal the sentence, it would have significantly delayed his release from custody. The Court, therefore, notes that the Convention seeks to guarantee not theoretical or illusory rights but rights which are practical and effective and agrees with the applicant's argument that the price for exercising his right to appeal would be his freedom, especially since the duration his detention would be uncertain.

In a separate opinion of the judge of the Ovruch district court of the Zhytomyr region from August 16, 2017, the judge drew the attention of the courts to the fact that when sentencing in each case and for each defendant convicted of a crime, must strictly comply with Art. 65 of the Criminal Code of Ukraine (2001) on the general principles of sentencing, because it is through the latter that the principles of legality, justice, reasonableness, and individualization of punishment are implemented and that when sentencing, in each case courts must comply with criminal law and take into account the severity of the crime, data on the identity of the perpetrator and mitigating and aggravating circumstances (Grishkovets, 2017).

Such punishment should be necessary and sufficient to correct the convict and prevent new crimes. At the same time, courts must take into account the requirements of the Criminal Procedure Code of Ukraine (2012). In a separate opinion, the judge also analyzed the case-law of the ECtHR, where the court emphasized that the main purpose of Article 6 of the Convention in criminal proceedings was to ensure a fair trial by a court that would establish the merits of any criminal charge and noted that the right to a fair trial 1 st. 6 of the Convention, should be interpreted in the context of the preamble to the Convention, which, in particular, proclaims the rule of law as part of the common heritage of the Contracting States.

All the above practice is applied by the courts of Ukraine, as seen from the Generalization of the practice of application by courts of general jurisdiction of first and appellate instances in criminal proceedings Articles 3, 5, 6 of the Convention for the Protection of Human Rights and Fundamental Freedoms 1950 for 2011 - first half of 2012.

Thus, the decisions of the ECtHR trace the dynamics of the implementation of the protective function of criminal law, which is reflected in the creation of prejudices for contracting states to protect law and order at the international level and ensure rights in each Contracting State to the Convention.

To comprehensively study the dynamics of the implementation of the security function in sentencing for criminal offenses in Ukraine, it is important to analyze the implementation of the investigated function in foreign countries.

In modern conditions, there are many legais systems that develop and interact with each other despite national and territorial differences. Issues 
of security and protection of human and civil rights in criminal proceedings and areas of activity: legislative - at the theoretical level, the relevant services - in practice.

The most successful experience in the field of protection of human and civil rights and freedoms, society, and the state, to date, have developed in those states that have a long legal tradition and extensive positive experience in this matter. These are primarily countries such as the United States, Great Britain, Australia, Canada, and New Zealand.

In the United States, the protective function of sentencing is implemented at a high level. But the problem was the relatively high level of protection of criminals and low guarantees for victims of crime. As proof of the success of the programs adopted in the United States, there is a witness protection program. Also with the growth of crime and the associated intensification of the movement to protect the rights of victims of crime, US law has equalized the rights of those accused of committing crimes and victims of crime.

The United Kingdom implemented the experience of protection of rights and freedoms through the Charter of Victims of Crime, which defined the mutual rights of victims and law enforcement agencies.

Canada has developed a system that protects every participant in criminal proceedings.

Because imprisonment is one of the most severe types of criminal punishment, in foreign countries in this context, a special protective function. Thus, the international community is following the path of humanization in the execution and serving of sentences for minors, as violations in sentencing continue to occur. At the international level, several documents have been adopted defining how it is necessary to ensure the protection of the rights of minors who have committed illegal acts. These include the 1985 Beijing Rules, which set minimum UN standard rules for the administration of criminal justice against minors; Riyadh guidelines, which set out the UN guidelines for the prevention of juvenile delinquency, as well as rules for the protection of juveniles deprived of their liberty.

The above documents are aimed primarily at the protection and defense of juvenile offenders in sentencing, which is quite justified, as this category of persons is particularly vulnerable and requires increased attention to the protection of their rights and interests.

Besides, in all European countries, a significant role is given to the application of ECtHR practice in sentencing. Thus, States parties to the Convention use the case-law of the ECtHR in sentencing national courts and are guided by the fundamental principles of the Convention on the Rule of Law and Access to Justice in Criminal Matters. 
Dariia Balobanova, Iryna Gorbachova, Anastasïa Otsyatsya, Mykhailo Dmytruk y Anastasiia Khylchenko

Thus, analyzing the dynamics of the protection function in sentencing for criminal offenses in Ukraine, it is important not only to analyze the general provisions, individual court decisions but also to consider the international experience of law enforcement practice of the ECtHR, as it allows to understand whether law enforcement, lack of proper legislation or perhaps the reason is the human factor.

\section{Discussion}

As a result of the study, the practice of the ECtHR and the dynamics of the implementation of the protective function in sentencing for criminal offenses in this context were analyzed.

To ensure the implementation of the security function, several conditions should be provided:

1. When establishing criminal liability for encroachment on public relations regulated by the rules of law, the set of legislative provisions must have a level of coherence that will contribute to the formation of a logical rule of law.

2. Criminal law, determining the basis of criminal liability for such violation, should have priority in establishing the basis of criminal liability because only this branch of law establishes the grounds and limits of criminal liability.

3. The provisions of other branches of law should not be mechanically repeated, but be transformed into an element of the system of norms of criminal law, adhering to their principles, rules for formulating the corpus delicti, etc.

4. Legislative terminology used by regulatory and criminal law should not differ in content.

5. When formulating legal norms and rules, it is necessary to pay attention to the fact that they should be based on the law and, if necessary, their content can only be specified in bylaws.

6. The provisions of the case-law of the ECtHR must play a key role and be reflected in legal norms. 


\section{Conclusions}

Thus, the analysis of the dynamics of the implementation of the protective function in sentencing for criminal offenses through a detailed review of the case-law of the European Court of Human Rights showed that several conditions must be met to ensure the rights of participants in criminal proceedings. First of all, it is the existence of both legislative consolidation and the actual implementation of international principles for the protection and enforcement of fundamental human and civil rights and public order. There must also be real mechanisms for appealing against the actions and decisions of the judiciary in the event of an unjust sentence or conviction without proven guilt. To eliminate the problems that arise during the consideration of criminal cases by the courts, it is necessary to improve the practice of investigating complaints of ill-treatment by representatives of the state in the context of the requirements of Art. 3 of the Convention.

These actions will contribute to the positive dynamics of the protection function in sentencing. Nevertheless, in the absence of effective mechanisms, there will be a decline in the implementation of the studied function and an outbreak of arbitrariness and lawlessness.

Regarding further scientific research in the study of the dynamics of the security function in sentencing for criminal offenses, it is important to analyze in detail the factors influencing the state of security, including internal (legislation, government policy, corruption of state authorities) and foreign (international policy, international agreements, sanctions, etc.), and not just the practice of the ECtHR.

\section{Bibliographic References}

ARBELÁEZ-CAMPILlO, Diego Felipe; ROJAS-BAHAMÓN, Magda J.; ARBELÁEZ-ENCARNACIÓN Tanya Fernanda. 2018. "Notes for the debate of the categories universal citizenship, human rights and globalization” In: Cuestiones Políticas. Vol. 34, No. 61, pp. 139-161.

CONSTITUTION OF UKRAINE. 2016. Law of June 28, 1996, No. 254k / 96VR. Revision of September 30, 2016, grounds - 1401-19. Available online. In: https://zakon.rada.gov.ua/laws/show/254\%Do\%BA/96\%Do\%B2\%D1\%80. Consultation date: 28/11/2019.

CRIMINAL CODE OF UKRAINE. 2001. Verkhovna Rada (Ukrainian Parliament). 2001, no. 2341-III. Available online. In: https://zakon.rada. gov.ua/laws/show/2341-14. Consultation date: 28/11/2019. 
Dariia Balobanova, Iryna Gorbachova, Anastasïa Otsyatsya, Mykhailo Dmytruk y Anastasiia Khylchenko

440

Dynamics of the implementation of the protective role in the conduct of crimes: the practice of the Convention for the Protection of Human Rights and Fundamental Freedoms

CRIMINAL PROCEDURE CODE OF UKRAINE. 2012. Verkhovna Rada (Ukrainian Parliament). 13.04.2012, no. 4651-VI. Available online. In: https://zakon.rada.gov.ua/laws/card/4651-17. Consultation date: 28/11/2019.

DROBUSH, Iryna; OLKINA, Olena; VODOPIAN, Tetiana; BUT, Illia. 2019. Constitutional guarantee of the right to judicial protection in disputes concerning the invalidity of a will as grounds for the acquisition of property rights in Ukraine. Amazonia Investiga. Vol. 8, No. 22, pp. 766772.

DROZDOV, Oleksandr. 2017. "NON BIS IN IDEM - A European guideline for ensuring the sustainability and unity of case law by the Supreme Court". In: Law of Ukraine. No. 6, pp. 110-132.

EUROPEAN COURT OF HUMAN RIGHTS. 1950. European convention on human RIGHTS. Available online. In: https:/www.echr.coe.int/ Documents/Convention_ENG.pdf. Consultation date: 28/11/2019.

EUROPEAN COURT OF HUMAN RIGHTS. 1999. Judgment in the case of Selmouni v. France of 28 July 1999. No. 25803/94. Refworld. Available online. In: https://www.refworld.org/cases,ECHR,3ae6b70210.html. Consultation date: 28/11/2019.

EUROPEAN COURT OF HUMAN RIGHTS. 2011. Judgment in the case of Mocallal v. Ukraine of 10 November 2011. (Application №19246 / 10). Available online. In: http://search.ligazakon.ua/l_doc2.nsf/link1/ SOOoo339.html/. Consultation date: 28/11/2019.

EUROPEAN COURT OF HUMAN RIGHTS. 2012. Judgment in the case of Grigoryevv.Ukraine of 15 May 2012. (Application no.51671/o7). Available online. In: https://zakon.rada.gov.ua/laws/show/974_833\#Text. Consultation date: 28/11/2019.

EUROPEAN COURT OF HUMAN RIGHTS. 2012. Judgment in the case of Iglin v. Ukraine of 12 January 2012. (Application no. 39908/05). Available online. In: https://zakon.rada.gov.ua/laws/show/974_780\#Text. Consultation date: 28/11/2019.

EUROPEAN COURT OF HUMAN RIGHTS. 2012. Judgment in the case of Klishin v. Ukraine of 23 February 2012. (Application №30671 / 04). Available online. In: http://search.ligazakon.ua/l_doc2.nsf/link1/ SOOoo389.html. Consultation date: 28/11/2019.

EUROPEAN COURT OF HUMAN RIGHTS. 2015. Judgment in the case of Ruslan Yakovenko v. Ukraine of 4 June 2015. (Application no. 5425/11). Available online. In: https://hudoc.echr.coe.int/fre\#\{\%22ite mid\%22:[\%22001-154978\%22]\}. Consultation date: 28/11/2019. 
GOTOROVA, Natalia O. 2014. Protective function of criminal law. The science of criminal law in the system of interdisciplinary relations. Available online. In: http://dspace.nlu.edu.ua/bitstream/123456789/7065/1/ Gutorova_31.pdf. Consultation date: 28/11/2019.

GRISHKOVETS, Alla Leonidivna. 2017. A separate opinion of a judge of the Ovruch District Court of the Zhytomyr Region of August 16, 2017. In: Liga36o. Available online. In: https://verdictum.ligazakon.net/ document/68339984. Consultation date: 28/11/2019.

KHILYUK, Svitlana Volodymyrivna. 2015. "Crime and Punishment in the Convention for the Protection of Human Rights and Fundamental Freedoms". In: Journal of the Academy of Advocacy of Ukraine. Vol. 8, No. 4, pp. 108-125.

KOLESNIKOV, Igor. 2019. Are Ukrainian judges ready for the amendment of the legislation - abuse of rights! Reasoning practice. In: National Bar Association of Ukraine. Available online. In: https://unba.org. ua/publications/print/4292-chi-gotovi-ukrains-ki-suddi-do-novelizakonodavstva-zlovzhivannya-pravom-mirkuvannya-praktika.html. Consultation date: 28/11/2019.

KOVALSKY, Victor. 2010. "The protective function of law: the question of historical conditionality". In: Legal Ukraine: Theory and History of State and Law. No. 2, pp.15-19.

LAW AND BUSINESS. 2012. Generalization of the practice of application by courts of general jurisdiction of the first and appellate instances in criminal proceedings of Articles 3, 5, 6 of the Convention for the Protection of Human Rights and Fundamental Freedoms of 1950 for 2011 - the first half of 2012. (n.d.). Available online. In: https://zib.com.ua/ua/ print/33771-uzagalnennya_praktiki_zastosuvannya_statey_3_5_6_ konvencii_p.html. Consultation date: 28/11/2019.

LAW OF UKRAINE. 2006. On the Enforcement of Judgments and the Practice of the European Court of Human Rights: Law of Ukraine of 23 February 2006, No. 3477-IV. Available online. In: https://zakon.rada.gov.ua/ laws/show/3477-15. Consultation date: 28/11/2019.

NAFIKOVA, Gulnara Aidarovna. 2010. "Protection of human and civil rights in foreign countries". In: Bulletin of Economics, Law and Sociology. No. 4, pp. 107-111.

SLUTSK, Tatyana Ivanovna. 2019. 250 legal positions of the ECtHR in criminal proceedings: updated, systematized selection. In: Protocol. Available online. In: https://protocol.ua/ua/250_pravovih_pozitsiy_espl_u_ 
Dariia Balobanova, Iryna Gorbachova, Anastasïa Otsyatsya, Mykhailo Dmytruk y Anastasiia Khylchenko

Dynamics of the implementation of the protective role in the conduct of crimes: the practice of the Convention for the Protection of Human Rights and Fundamental Freedoms

kriminalnomu_provadgenni_onovlena_sistematizovana_dobirka/. Consultation date: 28/11/2019.

TSIURA, Vadym; KHARCHENKO, Heorhii H.; SABODASH, Roman. 2020. The civil legal category of property rights in Ukraine in the context of ECtHR decisions: problems of theory and practice. Amazonia Investiga. Vol. 9, No. 26, pp. 197-204.

VASHAKIDZE, Natalya A. 2019. "Protection of the rights of juvenile offenders while serving sentences in different countries". In: Bulletin of the Moscow University of the Ministry of Internal Affairs of Russia. No. 4, pp. 131-135. 

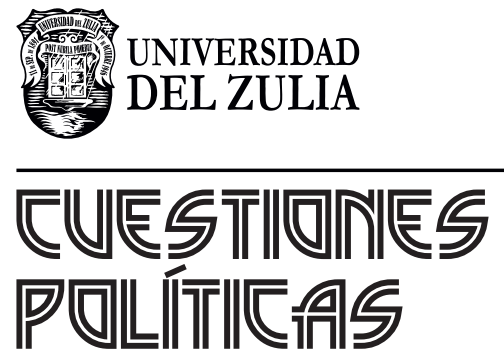

Vol.38 NEspecial

Esta revista fue editada en formato digital y publicada en diciembre de 2020, por el Fondo Editorial Serbiluz, Universidad del Zulia. Maracaibo-Venezuela 